\title{
Urgensi Pembatasan Kekuasaan Presiden Dalam Pengangkatan Wakil Menteri Pasca Reformasi ${ }^{1}$
}

\author{
Ahmad Ilham Wibowo dan Karina Maharani Alkhusna \\ Magister Hukum Kenegaraan FH UGM Yogyakarta Indonesia \\ Jln. Sosio Yustisia No. 1, Bulaksumur, Sleman, DIY Indonesia \\ ilhamwibowo01@gmail.com; karina.maharani33@gmail.com
}

\section{Received: 25 Oktober 2020; Accepted: 7 April 2021; Published: 2 Juni 2021}

DOI: 10.20885 /iustum.vol28.iss2.art3

\begin{abstract}
Law Number 39 of 2008 gives the president authority to appoint a Deputy Minister. However, the appointment of the Deputy Minister, both in terms of regulation and practice, did not restrict the power of the President as mandated by the 1945 Constitution after the reform. There are 2 problem formulations in this research: first, what are the dynamics of the post-reformation arrangements for the appointment of Deputy Minister for President? Second, what is the urgency of limiting the power of the President in appointing the Deputy Minister in post-reformation era? This is a normative research using statutory, conceptual, case and historical approaches. The results conclude that first, the arrangement of the presidential authority to appoint Deputy Minister has undergone various changes which resulted in a wide space for the President to appoint and determine the number of Deputy Minister. Second, there is an urgency to limit the power of the President to appoint Deputy Minister because the regulations in the State Ministry Law still has gaps in the domination of the President's political interests, not based on the existence of certain expertise for workloads that require special handling and not in line with the effectiveness and efficiency of the state ministries. Limitation of power can be carried out by providing clear terms and indicators and involving the DPR's considerations in the appointment of the Deputy Minister
\end{abstract}

Key Words: Appointment of Deputy Minister; limitation of presidential powers; presidential authority; post-reform

Abstrak

UU Nomor 39 Tahun 2008 memberikan kewenangan kepada presiden untuk dapat mengangkat Wakil Menteri (Wamen). Namun, pengangkatan Wamen baik dari segi pengaturan maupun praktiknya justru tidak membatasi kekuasaan Presiden sebagaimana diamanatkan UUD 1945 pasca reformasi. Terdapat 2 rumusan masalah dalam penelitian ini: pertama, bagaimana dinamika pengaturan pengangkatan Wamen oleh presiden pasca reformasi? Kedua, apa urgensi pembatasan kekuasaan presiden dalam pengangkatan Wamen pasca reformasi? Penelitian ini bersifat normatif dengan menggunakan pendekatan perundang-undangan, konseptual, kasus dan historis. Hasil penelitian menyimpulkan bahwa pertama, pengaturan kewenangan Presiden mengangkat Wamen mengalami berbagai perubahan yang mengakibatkan adanya ruang yang lebar bagi Presiden dalam mengangkat dan menentukan jumlah Wamen. Kedua, terdapat urgensi pembatasan kekuasaan Presiden mengangkat Wamen karena pengaturan dalam UU Kementerian Negara masih membuka celah dominasi kepentingan politik Presiden, bukan didasarkan atas adanya keahlian tertentu untuk beban kerja yang membutuhkan penanganan khusus dan tidak sejalan dengan efektivitas dan efisiensi kementerian negara. Pembatasan kekuasaan dapat dilakukan dengan memberikan syarat dan indikator yang jelas serta melibatkan pertimbangan DPR dalam pengangkatan Wamen.

Kata-kata Kunci : Kewenangan presiden; pasca reformasi; pengangkatan wamen; pembatasan kekuasaan presiden

1 Naskah ini didanai dari program "Hibah Penelitian Mahasiswa Tahun 2020" yang diadakan oleh Unit Riset dan Publikasi (URP) Fakultas Hukum Universitas Gadjah Mada. 


\section{Pendahuluan}

Indonesia merupakan salah satu negara yang menganut sistem presidensial sebagai pilihan atas sistem pemerintahannya. ${ }^{2}$ Sistem presidensial merupakan sistem pemerintahan yang menempatkan presiden sebagai kepala negara (head of state) sekaligus kepala pemerintahan (head of government). ${ }^{3}$ Sistem ini juga sering disebut sebagai concentration of governing power and responsibility upon the president, sehingga di atas presiden tidak ada lagi institusi lain yang lebih tinggi, kecuali konstitusi. ${ }^{4}$ Guna menjalankan fungsi pemerintahan ini, presiden dibantu oleh menteri-menteri yang ditunjuk oleh presiden itu sendiri. ${ }^{5}$

Undang-Undang Nomor 38 Tahun 2008 tentang Kementerian Negara (UU Kementerian Negara) juga memberikan kewenangan tambahan kepada presiden untuk dapat mengangkat Wakil Menteri (Wamen). Kedudukan Wamen tersebut dalam sistem ketatanegaraan Republik Indonesia adalah sebagai pembantu Menteri dalam melaksanakan tugas-tugas Menteri dan bertanggung jawab kepada Menteri.6 Pengangkatan Wamen yang diatur dalam Pasal 10 UU Kementerian Negara menyatakan bahwa "dalam hal terdapat beban kerja yang membutuhkan penanganan secara khusus, Presiden dapat mengangkat Wakil Menteri pada Kementerian tertentu. Penjelasan Pasal 10 UU Kementerian Negara kemudian menerangkan lebih lanjut bahwa "yang dimaksud dengan "wakil menteri" adalah pejabat karir dan bukan merupakan anggota kabinet". Pejabat karir ini kemudian diperinci harus berasal dari pegawai negeri yang telah menduduki jabatan struktural eselon I.a. ${ }^{7}$

Beberapa ketentuan pasal di atas memberikan legitimasi kewenangan kepada presiden untuk, (1) membentuk jabatan Wamen dengan syarat adanya beban kerja yang membutuhkan penanganan secara khusus; dan (2) mengangkat

${ }^{2}$ Lihat Pasal 4 ayat (1) UUD NRI 1945 yang menyatakan "Presiden Republik Indonesia memegang kekuasaan pemerintahan menurut Undang-Undang Dasar". Bahkan, dianutnya sistem presidensial ini merupakan kesepakatan pendiri bangsa sejak awal pembentukan UUD 1945, lihat M. Yasin al-Arif, "Anomali Sistem Pemerintahan Presidensial Pasca Amendemen UUD 1945”, dalam Jurnal Hukum Ius Quia Iustum, Vol. 22, No. 2, April, 2015, hlm. 239.

${ }^{3}$ Hanta Yuda, Presidensialisme Setengah Hati, Cetakan Pertama, Gramedia Pustaka Utama, Jakarta, 2010, hlm. 20-21.

4 Jimly Asshiddiqie, Format Kelembagaan Negara dan Pergeseran Kekuasaan dalam UUD 1945, FH UII Press, Yogyakarta, 2004, hlm. 76.

5 Lihat Pasal 17 UUD NRI 1945

${ }^{6}$ Aidin, "Kedudukan Wakil Menteri dalam Sistem Ketatanegaraan Republik Indonesia". Jurnal IUS Kajian Hukum dan Keadilan, Vol. II, No. 5, Agustus, 2014, hlm. 250.

7 Pasal 70 ayat (3) Peraturan Presiden Nomor 47 Tahun 2009 tentang Pembentukan dan Organisasi Kementerian Negara 
seseorang untuk menjadi Wamen dengan syarat berasal dari pegawai negeri yang telah menduduki jabatan struktural eselon I.a. Terlihat, frasa beban kerja yang membutuhkan penanganan secara khusus tidak memberikan indikator yang terukur dalam membentuk jabatan Wamen. Sedangkan, terhadap syarat mengangkat seseorang menjadi Wamen, diberikan batasan yang lebih ketat, yakni harus berasal dari pegawai negeri yang telah menduduki jabatan struktural eselon I.a.

Pada awal masa pemerintahan Presiden Susilo Bambang Yudhoyono (SBY) jilid kedua, diterbitkan Peraturan Presiden Nomor 76 Tahun 2011 tentang perubahan atas Peraturan Presiden No. 47 Tahun 2009 yang menghapuskan syarat Wamen harus berasal dari pegawai negeri yang telah menduduki jabatan struktural eselon I/a. dan dapat berasal dari non-pegawai negeri. Implikasinya, presiden kemudian dapat mengangkat seseorang menjadi Wamen baik berasal dari pegawai negeri atau nonpegawai negeri. Padahal, UU Kementerian Negara masih mengatur Wamen sebagai pejabat karir yang tentu diisi oleh pegawai negeri.

Perubahan pengaturan ini menjadi dasar bagi Presiden Susilo Bambang Yudhoyono (SBY) untuk mengangkat 19 (orang) Wamen pada periode kedua jabatannya (Kabinet Indonesia Bersatu Jilid II). ${ }^{8}$ Kebijakan pengangkatan Wamen ini kemudian menjadi salah satu dasar permohonan judicial review terhadap konstitutionalitas Wamen yang diatur dalam Pasal 10 UU Kementerian Negara ke MK. MK melalui Putusan No. 79/PUU-IX/2011 kemudian memutuskan bahwa keberadaan Wamen sah secara konstitutional. Namun, MK menghapuskan penjelasan Pasal 10 UU MK, sehingga Wamen tidak lagi berstatus sebagai pejabat karir dan dapat berasal dari kalangan manapun serta statusnya berubah menjadi jabatan politik, tidak lagi sebagai jabatan karir. ${ }^{9}$

Permasalahan yang kemudian muncul adalah, adanya pergeseran kedudukan Wamen menjadi jabatan politik ini, tidak diikuti oleh perubahan pengaturan pengangkatan Wamen dalam UU Kementerian Negara yang didasarkan atas adanya beban kerja yang membutuhkan penanganan secara khusus dalam suatu kementerian tertentu. Ketentuan tersebut memberikan ruang

8 “SBY Kini Punya 19 Wakil Menteri”, https://nasional.tempo.co/read/361705/sby-kini-punya-19wakil-menteri, diakses pada tangal 5 April 2020.

${ }_{9}$ Pasal 6 Peraturan Presiden Nomor 60 Tahun 2012 tentang Wakil Menteri menyatakan bahwa "Wakil menteri dapat berasal dari pegawai negeri atau bukan pegawai negeri”. 
penafsiran yang begitu lebar kepada presiden untuk membentuk jabatan Wamen dengan memaknai frasa beban kerja yang membutuhkan penanganan secara khusus dalam suatu kementerian tertentu. Selain itu, UU Kementerian Negara juga tidak mengatur syarat-syarat seseorang untuk diangkat menjadi Wamen. Padahal, terdapat perluasan syarat seseorang menjadi Wamen, yang dapat berasal dari pegawai negeri maupun non-pegawai negeri.

Lebarnya ruang presiden dalam mengangkat Wamen ini kemudian juga terlihat pada masa pemerintahan Presiden Jokowi periode kedua (Kabinet Indonesia Maju) yang mengangkat sebanyak 12 Wamen. Susunan Wamen tersebut terdiri dari 5 orang berlatar belakang profesional serta 7 orang dari basis pendukung jokowi, baik berasal dari Parpol atau berasal dari sukarelawan serta tim pemenangan jokowi-ma'aruf. ${ }^{10}$ Terlihat, susunan Wamen yang diangkat tidak lagi berasal dari unsur pegawai negeri dan kesemuanya berasal dari unsur nonpegawai negeri, baik dari kalangan profesional maupun partai politik.

Praktik ini kemudian mendapat kritikan tajam dari beberapa tokoh. Direktur Eksekutif Pusat Kajian Politik Universitas Indonesia yakni Aditya Perdana mengatakan bahwa pengangkatan 12 Wamen ini merupakan kompromi politik untuk mengakomodasi kepentingan pendukung Jokowi-Ma'ruf. ${ }^{11}$ Hal senada juga disampaikan oleh pengamat politik dari Lembaga Ilmu Pengetahuan Indonesia (LIPI) yakni Aisah Putri Budiarti yang mengatakan, jumlah Wamen yang begitu banyak akan berdampak terhadap efektivitas kerja dan anggaran Kementerian serta mempersulit koordinasi di Kementerian. ${ }^{12}$ Adanya beberapa kritikan ini menjadi gambaran, bahwa pengangkatan Wamen berpotensi untuk didominasi kepentingan politik presiden, bukan dilandasi untuk mewujudkan efektivitas dan efisiensi birokrasi serta memenuhi adanya keahlian tertentu guna mengatasi adanya beban kerja khusus yang menjadi dasar pengangkatan Wamen.

Uraian di atas memperlihatkan adanya ruang yang lebar bagi presiden dalam pengangkatan Wamen (pengangkatan Wamen dimaknai sebagai

10 "Komposisi Wakil Menteri Jokowi 5 dari Parpol, 5 dari Professional serta Timses", https://nasional.kompas.com/read/2019/10/25/16234391/komposisi-wakil-menteri-jokowi-5-dari-parpol-5 profesional-serta-timses-dan?page $=$ all, diakses pada tanggal 29 September 2020.

11 "Wakil Menteri Kabinet Jokowi; Antara Kompromi Politik dan Pemborosan Anggaran", https://www.bbc.com/indonesia/indonesia-50179625, diakses pada tangal 5 April 2020.

${ }^{12}$ Ibid 
membentuk jabatan Wamen dan mengangkat seseorang untuk menduduki jabatan Wamen) sehingga tidak terdapat ruang pembatasan kekuasaan bagi presiden. Padahal, salah satu agenda amendemen UUD 1945 pasca reformasi menghendaki adanya pembatasan kekuasaan terhadap presiden. ${ }^{13}$

\section{Rumusan Masalah}

Berdasarkan latar belakang masalah yang telah diuraikan sebelumnya, maka Penulis akan merumuskan masalah sebagai berikut: pertama, bagaimana dinamika pengaturan pengangkatan wakil menteri oleh presiden pasca reformasi? Kedua, apa urgensi pembatasan kekuasaan presiden dalam pengangkatan wakil menteri pasca reformasi?

\section{Tujuan Penelitian}

Berdasar uraian tulisan ini difokuskan utuk mengkaji lebih lanjut mengenai dua hal, yaitu: pertama, untuk mengetahui dinamika pengaturan wakil menteri pasca reformasi. Kedua, untuk mengetahui urgensi pembatasan kekuasaan presiden dalam mengangkat wakil menteri pasca reformasi.

\section{Metode Penelitian}

Penelitian ini termasuk ke dalam jenis penelitian hukum normatif yang mengkonsepsikan hukum sebagai norma meliputi nilai-nilai, hukum positif, dan putusan pengadilan. Terdapat 4 pendekatan yang digunakan penulis yakni, (1) pendekatan perundangan-undangan; (2) pendekatan konseptual; (3) pendekatan kasus; dan (4) pendekatan historis.

Penelitian ini menggunakan 3 Bahan hukum yang digunakan terdiri dari, pertama, bahan hukum primer yakni bahan yang mempunyai kekuatan mengikat secara yuridis seperti peraturan perundang-undangan, bahan hukum primer dalam penelitian ini meliputi; (1) Undang-Undang Dasar Negara Republik Indonesia Tahun 1945 sebelum amandemen dan setelah amandemen; (2) Undang-Undang Nomor 39 Tahun 2008 tentang Kementerian Negara; (3) Peraturan Presiden Nomor 47 Tahun 2009 jo Peraturan Presiden Nomor 76 Tahun 2011 tentang Pembentukan dan

13 Margarito Kamis, Pembatasan Kekuasaan Presiden: Pergeseran Kekuasaan Presiden Pasca Amendemen UUD 1945, Cetakan Pertama, Setara Press, Malang, 2014, hlm. 3-11. 
Organisasi Kementerian Negara; (4) Peraturan Presiden Nomor 60 Tahun 2012 tentang Wakil Menteri; (5) Putusan Mahkamah Konstitusi Nomor 79/PUU-IX/2011 tentang Pengujian terhadap Undang-Undang-Undang Nomor 39 Tahun 2008 tentang Kementerian Negara; (6) Naskah Komprehensif Perubahan UUD NRI 1945 Tahun 1945 buku IV tentang Kekuasaan Pemerintahan Negara Jilid 2; dan (7) Risalah Rapat Kerja Panitia Khusus RUU Tentang Kementerian Negara. Kedua, bahan hukum sekunder, berupa buku, jurnal, penelitian, kepustakaan hukum yang berlaku di negara lain yang berhubungan dengan objek penelitian.

Penelitian ini dilakukan dengan 2 cara: (1) studi pustaka dengan mengkaji jurnal, hasil penelitian hukum, dan literatur yang berhubungan dengan permasalahan penelitian; dan (2) studi dokumen dengan mengkaji berbagai dokumen resmi institusional berupa peraturan perundang-undangan yang berhubungan dengan permasalahan penelitian. Penelitian ini adalah analisis data kualitatif, meliputi kegiatan pengklasifikasian data, editing, penyajian hasil dalam bentuk narasi, dan pengambilan kesimpulan.

\section{Hasil Penelitian dan Pembahasan}

\section{Dinamika Pengaturan Pengangkatan Wakil Menteri oleh Presiden Pasca Reformasi}

Tercatat pasca reformasi, pengaturan kewenangan presiden untuk mengangkat Wakil Menteri (Wamen) baru hadir dalam Undang-Undang Nomor 39 Tahun 2008 tentang Kementerian Negara (UU Kementerian Negara). Pengaturan tersebut diatur dalam Pasal 10 UU Kementerian Negara yang menyatakan bahwa "dalam hal terdapat beban kerja yang membutuhkan penanganan secara khusus, Presiden dapat mengangkat Wakil Menteri pada Kementerian tertentu. Penjelasan Pasal 10 UU Kementerian Negara kemudian menyatakan bahwa "yang dimaksud dengan "wakil menteri" adalah pejabat karir dan bukan merupakan anggota kabinet". Terlihat, ketentuan terkait pengangkatan Wamen dalam UU Kementerian Negara hanya bersandar pada ketentuan Pasal 10 UU Kementerian Negara beserta penjelasannya.

Ketentuan Pasal 10 UU Kementerian Negara menegaskan kewenangan presiden untuk membentuk jabatan Wamen serta mengangkat seseorang menjadi 
Wamen dengan syarat adanya beban kerja yang membutuhkan penanganan secara khusus. Namun, frasa beban kerja yang membutuhkan penanganan secara khusus justru tidak memberikan parameter yang jelas dan terukur sehingga memberikan ruang yang lebar bagi presiden dalam membentuk jabatan Wamen serta mengangkat seseorang menjadi Wamen.

Apabila dilihat dalam penjelasan Pasal 10 UU Kementerian Negara menentukan status Wamen sebagai pejabat karir. Implikasi sebagai pejabat karir, maka Wamen diisi oleh seseorang yang berasal dari birokrat pemerintah atau pegawai negeri yang telah memenuhi kompetensi dan kriteria karir birokrasi tertentu. ${ }^{14}$ Namun, UU Kementerian Negara juga tidak menegaskan kompetensi dan kriteria karir birokrasi seperti apa yang harus dimiliki pegawai negeri untuk dapat diangkat menjadi Wamen. Status Wamen sebagai pejabat karir ini berbeda dengan status Menteri yang diletakkan sebagai pejabat politik yang dapat berasal dari non birokrasi baik dari kalangan profesional maupun politik.

Ditentukan pula kedudukan Wamen bukan sebagai anggota kabinet tetapi tidak terdapat penjelasan yang jelas mengenai penegasan kedudukan Wamen bukan sebagai anggota kabinet ini. Walaupun demikian, dapat diindikasikan bahwa, penegasan kedudukan Wamen bukan sebagai anggota kabinet ini untuk menegaskan status Wamen sebagai jabatan karir, bukan sebagai jabatan politik karena tidak diinginkan dimasukkan sebagai anggota kabinet.

Guna menemukan kejelasan pengaturan Wamen dalam UU Kementerian Negara, maka penulis mencoba menganalisis original intent pengaturan pengangkatan Wamen melalui Risalah Rapat Kerja Panitia Khusus RUU Tentang Kementerian Negara. Dalam risalah, Permadi, selaku Ketua Panitia Kerja dari Fraksi PDIP menyatakan sebagai berikut. ${ }^{15}$

Dua Panja dapat menerima usulan Tim Perumus untuk ditambah pasal baru, Pasal 10 yang mengatur bahwa Presiden dapat mengangkat Wakil menteri pada Kementerian yang menangani urusan tertentu. Hal tersebut mengingat fakta pada saat ini, telah diangkat Wakil Menteri Luar Negeri. Sedangkan ke depan diharapkan

\footnotetext{
14 Putusan MK Nomor 79/PUU-IX/2011 mengenai Pengujian UU No. 39 Tahun 2008 tentang Kementerian Negara, hlm. 68.

${ }^{15}$ DPR RI, Risalab Rapat Kerja Panitia Khusus RUU Tentang Kementerian Negara, Kamis 16 Oktober 2008, hlm. 5 .
} 
tidak hanya Wakil Menteri Luar Negeri, tetapi pada Kementerian yang menangani urusan tertentu yang dianggap tepat untuk dapat diangkat seorang Wakil Menteri.

Tidak terdapat pertentangan pendapat terkait adanya kewenangan presiden untuk mengangkat Wamen baik dari Pemerintah maupun DPR sebagaimana Agun Gunandjar Sudarsa selaku Ketua Rapat dalam pembahasan Pasal 10 yang mengatur ketentuan tersebut menyatakan bahwa,16 "...Sebetulnya yang di Pasal 10 ini ada di halaman 5 ... Sebetulnya tidak ada permasalahan. Pihak DPR juga sudah setuju, pihak Pemerintah juga setuju". Lebih lanjut ia menyatakan sebagai berikut. ${ }^{17}$

Karena ini substansi baru di mana rumusannya dalam hal terdapat beban kerja yang membutuhkan penanganan secara khusus, Presiden dapat mengangkat Wakil Menteri pada Kementerian tertentu artinya posisi pengangkatan Wakil Menteri ini menjadi hak sepenuhnya Presiden dan Kementerian apa saja yang membutuhkan Wakil, tentunya Presiden yang mengetahui beban-beban kerja itu.

Berdasarkan uraian di atas, terlihat original intent pembentukan Wamen yakni untuk membantu tugas menteri sebagaimana fungsi Wamen Luar Negeri yang saat itu sudah ada di Kementerian Luar Negeri sehingga dengan adanya pengaturan dalam peraturan setingkat undang-undang akan menguatkan kedudukan Wamen. Dapat dilihat pula bahwa pertimbangan Presiden dapat mengangkat Wamen dan menentukan Kementerian yang membutuhkannya karena Presiden dianggap yang paling mengetahui beban-beban kerja tersebut.

Dinamika dalam pembahasan pengaturan pengangkatan Wamen terjadi saat Abdul Gafur dari fraksi Partai Golkar mempertanyakan status Wamen apakah termasuk dalam kabinet atau tidak. Beliau menyatakan sebagai berikut. ${ }^{18}$

... Kita punya Wakil Menteri Luar Negeri sekarang ini bukan Kabinet Minister, dia dilantik oleh Menlu padahal di sini bunyinya Presiden dapat mengangkat Wakil Menteri pada kementerian tertentu.... Itu nanti bagaimana itu prakteknya.... Karena supaya dia jangan jadi rancu dia.... Tolong statusnya diperjelas betul ini kabinet minister atau bukan karena wakil menteri is not kabinet minister.

Terhadap pertanyaan Abdul Gafur tersebut, Hatta Radjasa selaku Mensesneg memberikan jawabannya dengan menyatakan sebagai berikut. ${ }^{19}$

\footnotetext{
${ }^{16}$ Ibid., hlm. 7

${ }^{17}$ Ibid.

${ }^{18}$ Ibid., hlm. 17

${ }^{19}$ Ibid.
} 
... Wakil Menlu itu adalah bukan Kabinet Minister, bukan anggota kabinet. Oleh sebab itu Wakil Menlu dilantik oleh Menlu dan beliau adalah pejabat eselon I. Nah oleh sebab itu tentu yang kita maksudkan di dalam ini pun bukanlah anggota kabinet karena anggota kabinet kita ada 34. Kalau wakilnya anggota kabinet, pasti akan melampaui jumlah 34 itu dan ini memang sebagaimana juga kita di dalam ini juga disebutkan sangat selektif kepada departemen-departemen atau kementerian yang memang dirasakan memerlukan jabatan seorang wakil menteri yang lebih banyak bersifat ke dalam.

Terkait jumlah 34 tersebut dapat dilihat pertimbangannya sebagaimana dinyatakan oleh Mensesneg Hatta Radjasa sebagai berikut. ${ }^{20}$

Undang-Undang Kemeneterian Negara, selain mengatur beberapa hal yang kami kemukakan tadi juga memuat aturan mengenai pembatasan jumlah kementerian. Jumlah-jumlah kementerian ini sejalan dengan niat kita bersama untuk terus melakukan reformasi birokrasi. Undang-Undang ini menitikberatkan pada peningkatan pelayanan public yang prima sehingga pemerintahan dapat berjalan dengan efektif dan efisien.

Berdasarkan penjabaran risalah sidang di atas, maka dapat dilihat bahwa penentuan status Wamen sebagai pejabat karir juga dipicu oleh status Wamen dalam Kemenlu yang memang berasal dari pejabat karir. Sedangkan, penegasan penentuan kedudukan Wamen bukan sebagai anggota kabinet dipicu oleh adanya kesepakatan/resultante untuk membatasi jumlah anggota kabinet sebanyak 34 yang berlandaskan semangat reformasi birokrasi. Oleh karenanya, original intent pembentukan UU Kementerian Negara sedari awal menempatkan Wamen sebagai jabatan karir, bukan sebagai jabatan politik.

Ketentuan lebih lanjut terkait jabatan karir ini diperinci lewat pengaturan Pasal 70 ayat (3) Peraturan Presiden Nomor 47 Tahun 2009 tentang Pembentukan dan Organisasi Kementerian Negara (Perpres No. 47 Tahun 2009) yang mengatur syarat Wamen harus berasal dari pegawai negeri yang telah menduduki jabatan struktural eselon I.a. Ketentuan ini membatasi kriteria seseorang yang dapat diangkat menjadi Wamen oleh presiden, yakni merupakan pegawai negeri yang telah menduduki jabatan struktural eselon I.a.

Pada awal masa pemerintahan Presiden Susilo Bambang Yudhoyono (SBY) syarat telah menduduki jabatan struktural eselon I.a ini kemudian dihapus lewat

${ }^{20}$ Ibid., hlm. 27 
Perpres No. 76 Tahun 2011 tentang Perubahan atas Perpres No. 47 Tahun 2009 (Perpres No. 76 Tahun 2011). Implikasinya, Wamen tidak harus berasal dari pegawai negeri yang telah menduduki jabatan struktural eselon I/a. Perubahan ini membuka celah lebih lebar kepada Presiden SBY untuk mengangkat pejabat yang akan mengisi jabatan Wamen, karena tidak lagi dibatasi syarat berasal dari pegawai negeri yang telah menduduki jabatan struktural eselon I.a. Implikasinya, presiden dapat mengangkat seseorang untuk menjadi Wamen baik berasal dari pegawai negeri atau bukan pegawai negeri.

Terdapat intervensi politik yang cukup kuat dalam perubahan ini, karena dilakukan di tengah isu adanya reshuffle kabinet pada periode pemerintahan SBY. Kondisi politik ini juga ditangkap oleh Fajrul Falakh yang memandang bahwa, perubahan status Wamen yang tidak harus berasal dari pegawai negeri yang telah menduduki jabatan struktural eselon I.a ini mengindikasikan bahwa presiden menginginkan tambahan kekuasaan untuk menunjuk pejabat. Adanya penegasan status Wamen "sebagai pejabat karier" dalam penjelasan Pasal 10 UU Kementerian Negara tidak menghilangkan statusnya sebagai political appointee (kekuasaan pejabat politik terpilih untuk mendudukkan orang-orang kepercayaannya pada suatu jabatan) yang oleh Fajrul Falakh dinamakan sebagai konsep politisasi jabatan karier. $^{21}$

Dihapuskannya syarat Wamen harus berasal dari pegawai negeri yang telah menduduki jabatan struktural eselon I.a dalam Perpres No. 76 Tahun 2011 ini kemudian menjadi dasar bagi Presiden Susilo Bambang Yudhoyono (SBY) untuk mengangkat 19 (orang) Wamen pada periode kedua jabatannya (Kabinet Indonesia Bersatu Jilid II). Tercatat, unsur Wamen yang diangkat berasal dari 7 orang birokrat dan 12 orang berasal dari non birokrat/profesional. Unsur Wamen ini menunjukan bahwa Wamen tidak lagi hanya berasal dari pegawai negeri.

Kebijakan Presiden SBY mengangkat Wamen secara besar-besaran ini kemudian menjadi pemicu diajukannya judicial review terhadap ketentuan Pasal 10 UU Kementerian Negara oleh Gerakan Nasional Pemberantasan Tindak Pidana Korupsi (GN-PK). GN-PK sebagai pemohon mendalilkan bahwa

${ }^{21}$ Lebih lanjut lihat pendapat Fajrul Falaakh dalam Mohammad Saihu, dkk. Mohammad Fajrul Falaakh Konsisten Mengawal Konstitusi, Cetakan Pertama, Perpustakaan Nasional RI, Jakarta, 2014, hlm. 314-316. 
keberadaan Wamen tidak memiliki landasan konstitutional dalam UUD 1945. Selain itu, penjelasan Pasal 10 UU Kementerian Negara yang mengatur syarat Wamen harus dari pejabat karir juga dianggap membatasi hak warga negara untuk menduduki jabatan Wamen.

MK kemudian memutus permohonan ini lewat Putusan MK Nomor 79/PUU-IX/2011. Terhadap permohonan terkait konstitutionalitas Wamen, MK berpandangan bahwa kewenangan presiden untuk mengangkat Wamen adalah konstitusional. MK menggunakan penafsiran secara luas dengan memasukan pengangkatan Wamen sebagai bagian dari kewenangan Presiden walaupun UUD NRI 1945 tidak memberikan perintah maupun larangan. Dalil ini dikeluarkan dengan mendasarkan pada asas umum di dalam hukum bahwa "sesuatu yang tidak diperintahkan dan tidak dilarang itu boleh dilakukan" dan pengaturannya dimasukkan dalam undang-undang sepanjang tidak berpotensi melanggar hakhak konstitusional atau ketentuan-ketentuan lain di dalam UUD 1945.22 Pertimbangan hukum MK ini mengakibatkan adanya perluasaan kekuasaan presiden untuk dapat mengangkat pejabat dalam hal ini mengangkat Wamen.

MK menyatakan bahwa terhadap frasa "beban kerja yang membutuhkan penanganan khusus" menjadi wewenang Presiden untuk menentukan dan menafsirkannya sebelum mengangkat wakil menteri karena undang-undang tidak menjelaskannya. ${ }^{23}$ Namun di sisi lain, MK juga menyatakan bahwa ketika presiden mengangkat Wamen dalam rangka menangani beban kerja yang semakin berat itu tidak boleh bertentangan dengan konstitusi jika dipandang dari sudut pengutamaan tujuan yang hendak dicapai (doelmatigheid) atau nilai kemanfaatan dalam rangka memenuhi harapan dan kebutuhan masyarakat yang terus meningkat.24 Pertimbangan MK ini menjadikan ukuran digunakannya nilai kemanfaatan dalam rangka memenuhi kebutuhan masyarakat yang terus meningkat sebagai parameter dalam menafsirkan "beban kerja yang membutuhkan penanganan khusus" yang menjadi landasan/ratio bagi presiden untuk mengangkat Wamen.

\footnotetext{
22 Lihat pendapat mahkamah dalam Putusan MK Nomor 79/PUU-IX/2011, hlm. 74

${ }^{23}$ Lihat pendapat mahkamah dalam Putusan MK Nomor 79/PUU-IX/2011, hlm. 76

${ }^{24}$ Lihat pendapat mahkamah dalam Putusan MK Nomor 79/PUU-IX/2011, hlm. 77
} 
MK berpendapat mengenai inkonstitusionalitas Penjelasan Pasal 10 UU Kementerian Negara yang mengatur persyaratan Wamen harus berasal dari pejabat karir dan bukan merupakan anggota kabinet. Pertimbangan tersebut didasarkan pada 3 pandangan bahwa: ${ }^{25}$

1. ketentuan tersebut dalam implementasinya justru menimbulkan ketidakpastian hukum karena tidak sesuai dengan hukum kepegawaian atau peraturan perundang-undangan di bidang pemerintahan atau birokrasi.;

2. ketentuan penjelasan tersebut justru mencantumkan rumusan yang berisi norma;dan

3. ketentuan tersebut membelenggu kewenangan eksklusif presiden dalam hal mengangkat dan memberhentikan menteri/Wamen karena mengandung persoalan legalitas yang tentunya tidak boleh dilanggar oleh presiden.

MK memandang bahwa terdapat persoalan legalitas akibat diaturnya penjelasan Pasal 10 UU Kementerian Negara yang secara garis besar, mendalikan bahwa, penegasan status Wamen sebagai jabatan karir dalam UU Kementerian Negara diatur secara kurang matang sehingga dalam prakteknya justru menggeser status Wamen sebagai jabatan politik selayaknya menteri, sehingga dalam proses pengangkatannya membuka celah munculnya praktek bagi-bagi jabatan politik dan dianggap tidak sejalan dengan filosofi pembentukan UU Kementerian Negara untuk membatasi agar dalam membentuk kementerian negara presiden melakukannya secara efektif dan efisien. ${ }^{26}$

Putusan MK untuk menyatakan konstitutionalitas presiden mengangkat Wamen dibarengi dengan membatalkan penjelasan Pasal 10 UU Kementerian Negara, justru memberikan celah lebih lebar bagi presiden untuk mengangkat Wamen. Hal ini karena status Wamen tidak ditegaskan lagi sebagai jabatan karir dan kedudukannya juga tidak ditegaskan lagi bukan sebagai anggota kabinet. Implikasinya, status Wamen bergeser menjadi jabatan politik sehingga bisa diisi dari kalangan manapun, baik pegawai negeri/birokrat ataukah non-pegawai negeri baik dari kalangan profesional maupun politik.

\footnotetext{
${ }^{25}$ Lihat pendapat mahkamah dalam Putusan MK Nomor 79/PUU-IX/2011, hlm. 77-81

${ }^{26}$ Lihat Pendapat Mahkamah dalam Putusan MK Nomor 79/PUU-IX/2011, hlm. 77-80
} 
Kondisi ini diperberat lewat pengaturan dalam UU Kementerian Negara yang hanya menentukan frasa beban kerja yang membutuhkan penanganan khusus sebagai parameter bagi presiden untuk mengangkat Wamen. Oleh karenanya, adanya Putusan MK ini justru masih membuka ruang munculnya praktek bagi-bagi jabatan politik dalam pengangkatan Wamen sehingga tidak sejalan dengan filosofi pembentukan UU Kementerian Negara untuk membatasi agar dalam membentuk kementerian negara presiden melakukannya secara efektif dan efisien.27

Lebarnya ruang presiden untuk mengangkat Wamen dari non-pegawai negeri ini juga tercermin di masa pemerintahan Presiden Jokowi periode kedua (Kabinet Indonesia Maju) yang mengangkat sebanyak 12 Wamen. Susunan Wamen tersebut terdiri dari 5 orang berlatar belakang profesional, 5 orang dari unsur politik, dan 2 orang dari unsur sukarelawan pemenangan Jokowi-Ma'aruf Amin. ${ }^{28}$

Terlihat, susunan Wamen yang diangkat oleh Jokowi tidak lagi berasal dari unsur pegawai negeri dan bahkan kesemuanya berasal dari unsur non-pegawai negeri (baik dari kalangan profesional maupun partai politik). Bahkan, dalam kementerian BUMN justru diangkat 2 orang Wamen. Selain itu, terlihat lebih dari 50\% pos Wamen (7 dari 12 Wamen) diisi dari basis pendukung Jokowi, baik yang berasal dari Parpol maupun sukarelawan. Adanya praktek ini justru mencerminkan adanya fenomena bagi-bagi jabatan politik dalam pengangkatan Wamen.

\section{Urgensi Pembatasan Kekuasaan Presiden dalam mengangkat Wamen Pasca Reformasi}

Salah satu semangat yang menjiwai agenda amendemen UUD 1945 pasca reformasi adalah semangat pembatasan kekuasaan terhadap presiden. ${ }^{29}$ Adanya semangat pembatasan kekuasaan presiden ini dilatarbelakangi oleh praktek jalannya pemerintahan sebelum reformasi yang meletakkan kekuasaan yang begitu besar di tangan presiden (executive heavy) tanpa disertai dengan adanya checks and balances. ${ }^{30}$ Margarito Kamis menyatakan, bahwa UUD 1945 sebelum

27 Lihat Pendapat Mahkamah dalam Putusan MK Nomor 79/PUU-IX/2011, hlm. 78

28 “Komposisi Wakil Menteri Jokowi 5 dari Parpol, 5 dari Professional serta Timses", Loc. Cit

${ }^{29}$ Lihat Margarito Kamis, Pembatasan Kekuasaan Presiden.., Loc. Cit.

30 lebih lanjut lihat Ni'matul Huda, Hukum Tata Negara, Cetakan Pertama, RajaGrafindo Persada, Jakarta, 2006, hlm. 150 . 
amendemen yang terlalu executive heavy memungkinkan kekuasaan eksekutif hampir tidak terbatas. Padahal kekuasaan tidak dapat diminta untuk membatasi dirinya menurut semangat penyelenggaranya, namun kekuasaan harus dibatasi melalui alokasi kekuasaan secara limitatif dan tegas. ${ }^{31}$

Prinsip pembatasan kekuasaan merupakan salah satu ciri dari negara hukum yang demokratis yang menegaskan bahwa "kekuasaan selalu ada batasnya" dan pemerintah yang terbatas kekuasaanya (limited government), merupakan ciri khas demokrasi konstitusional. ${ }^{32}$ Paham pembatasan kekuasaan ini lahir sebagai antisipasi atas peletakkan kekuasaan secara terpusat dan terkonsentrasi di satu tangan. Seperti adagium dari Lord Acton, bahwa power tends to corrupt, absolute power corrupt absolutely yang bermakna bahwa kekuasaan di satu tangan cenderung untuk disalahgunakan. ${ }^{33}$

Pembatasan kekuasaan pemerintah ini dilakukan lewat aturan hukum (government limited by law). ${ }^{34}$ Selain itu, pembatasan kekuasaan pemerintah ini juga dilakukan melalui adanya pemisahan kekuasaan (separation of power). ${ }^{35}$ Kekuasaan dipisah menjadi 3 cabang, yakni kekuasaan eksekutif untuk menjalankan undang-undang, kekuasaan legislatif untuk membentuk undangundang, serta kekuasaan yudikatif untuk mengadili terhadap pelanggaran undang-undang. ${ }^{36}$ Pada perkembangannya, paham pemisahan kekuasaan tidaklah dapat dipisahkan secara strict atau mutlak (pure separation of power) sehingga memunculkan adanya mekanisme check and balance.

Prinsip checks and balances merupakan prinsip yang menempatkan ketiga cabang kekuasaan (legislatif, eksekutif, dan yudikatif) itu sama-sama sederajat dan saling mengontrol satu sama lain. ${ }^{37}$ Penerapan prinsip pemisahan kekuasaan dengan mekanisme check and balances ini dianggap sebagai prinsip yang saat ini

\footnotetext{
31 Margarito Kamis, Kekuasaan Presiden Indonesia Sejarah Kekuasaan Presiden Sejak Merdeka Hingga Reformasi Politik, Setara Press, Malang, 2014, hlm.84.

32 Ibid., hlm.67.

${ }^{33}$ Miriam Budiarjo, Dasar-Dasar Imu Politik, edisi revisi, Gramedia, Jakarta, 2008, hlm.107.

34 Govenrment limited by law merupakan salah satu unsur pokok dari negara hukum (rule of law). Lihat Brian Z. Tamanaha, "The History and Elements of The Rule Of Law", Singapore Journal of Legal Studies, 2012, hlm.236.

35 Prinsip pemisahan kekuasaan ini juga menjiwai UUD NRI 1945, Lihat Muntoha, "Demokrasi dan Negara Hukum”, Jurnal Hukum, Vol. 16, No. 3, Juli, 2009, hlm. 392. Lihat juga M.Termosjuizent, “The Concept Rule Of Law", Jentera, Edisi 3, Tahun II, November, 2004, hlm. 111

36 Saldi Isra, Pergeseran Fungsi Legislatif: Menguatnya Model Legislasi Parlementer Dalam Sistem Presidensial di Indonesia, Rajawali Pers, Jakarta, 2010, hlm. 39.

${ }^{37}$ Ni'matul Huda, Hukum Tata Negara..., Op. Cit., hlm. 107.
} 
paling efektif untuk mewujudkan adanya pembatasan kekuasaan dalam suatu negara.

Sri Soemantri menyatakan, bahwa pembatasan kekuasaan oleh hukum menurut Sri Soemantri menyangkut dua hal, yaitu, ${ }^{38}$ (1) berkenaan dengan isi kekuasaan; dan (2) berkenaan dengan waktu dalam mana kekuasaan itu dijalankan. Munir Fuady mengatakan, bahwa mekanisme pelaksanaan prinsip checks and balances diwujudkan lewat beberapa macam bentuk, seperti, ${ }^{39}$

1. pemberian kewenangan terhadap suatu tindakan kepada lebih dari satu cabang pemerintahan;

2. pemberian kewenangan pengangkatan pejabat tertentu kepada lebih dari satu cabang pemerintahan;

3. upaya hukum impeachment dari cabang pemerintahan yang satu terhadap cabang pemerintahan lainnya;

4. pengawasan langsung dari satu cabang terhadap cabang pemerintahan lainnya;dan

5. pemberian kewenangan kepada pengadilan sebagai pemutus akhir bila ada konflik kewenangan antara eksekutif dan legislatif.

Praktik pembatasan kekuasaan terhadap presiden dalam amendemen UUD 1945 dilakukan hampir terhadap semua kewenangan presiden yang harus dilakukan dengan pertimbangan DPR. ${ }^{40}$ Pengaturan ini menerapkan bentuk pembatasan kekuasaan presiden dengan meletakkan adanya kekuatan penyeimbang bagi kekuasaan presiden yang dalam hal ini diletakkan di tangan presiden dan DPR.

Pembatasan kekuasaan terhadap presiden juga diletakkan terhadap kewenangan presiden dalam membentuk, mengubah, dan membubarkan kementerian yang harus diatur dengan undang-undang. ${ }^{41}$ Pembatasan ini terjadi sebagai respon atas praktik pada masa sebelum amendemen UUD 1945 yang terkait jumlah dan ketentuan kementerian sangat ditentukan oleh kebutuhan dan kepentingan politik presiden. ${ }^{42}$ Contohnya, seperti praktek pada masa Presiden

\footnotetext{
${ }^{38}$ Ni'matul Huda, Presiden \& Pembantu Presiden dalam Sistem Ketatanegaraan Indonesia, Cetakan Pertama, FH UII Press, Yogyakarta, 2019, hlm. 174.

${ }^{39}$ Munir Fuadi, Teori Negara Hukum Modern (rechtstaat), PT. Refika Aditama, Bandung, 2009, hlm. 124.

40 Pasal 11, 12, 13, dan 14 UUD 1945

${ }^{41}$ Lihat Pasal 17 ayat (4) UUD NRI 1945 yang menyatakan bahwa pembentukan, pengubaban, dan pembubaran kementerian negara diatur dengan undang-undang.

42 Presiden memiliki kewenangan secara tunggal dalam bidang kementerian negara lewat pengaturan Pasal 17 UUD 1945 menyatakan bahwa "menteri-menteri itu diangkat dan diperhentikan oleb Presiden".
} 
Gus Dur yang kemudian menghasilkan penghapusan kementerian penerangan dan kementerian sosial.43

Adanya perintah pengaturan lewat undang-undang ini memberikan adanya aturan main (rule of game) serta kepastian parameter bagi presiden dalam melakukan pembentukan, pengubahan, dan pembubaran kementerian negara sehingga presiden tidak dapat menjalankan kewenangan secara sebebasbebasnya. Pembatasan kekuasaan presiden dalam bidang kementerian negara ini kemudian terwujud dalam Undang-Undang Nomor 39 Tahun 2008 tentang Kementerian Negara (UU Kementrian Negara). ${ }^{4}$

UU Kementrian Negara selain mengatur adanya pembatasan kekuasaan presiden membentuk dan mengangkat menteri, ternyata juga memperluas kekuasaan presiden dengan diberikannya kewenangan untuk mengangkat Wakil Menteri (Wamen). Dikatakan baru karena ketentuan Pasal 17 UUD NRI 1945 sama sekali tidak menyebutkan secara eksplisit adanya kewenangan presiden dalam mengangkat Wamen. ${ }^{45}$ Konstitusionalitas kewenangan presiden mengangkat Wamen kemudian diuji ke Mahkamah Konstitusi.

MK melalui Putusan No. 79/PUU-IX/2011 kemudian memberikan tafsir konstitutional bahwa kewenangan presiden mengangkat Wamen itu sah secara konstitutional. MK juga mendalilkan bahwa pengangkatan Wamen merupakan bagian dari kewenangan presiden untuk melaksanakan tugas-tugasnya. Tafsir MK ini mengakibatkan adanya perluasan kekuasaan presiden yang diwujudkan lewat adanya kewenangan presiden mengangkat Wamen. Oleh karenanya, sebagai bagian dari kekuasaan presiden, maka dapat dikatakan bahwa kewenangan presiden dalam mengangkat Wamen juga dilekati dengan semangat pembatasan kekuasaan terhadap presiden sebagai semangat yang menjiwai UUD NRI 1945.

Pengaturan kewenangan presiden dalam mengangkat Wamen dalam UU Kementerian Negara ternyata masih memberikan kekuasaan yang begitu besar di

${ }^{43}$ Ni'matul Huda, Presiden dan Pembantu Presiden..., Op. Cit., hlm. 301.

${ }^{44}$ Lihat Pasal 13,15,16,18 ayat (2), 19, 21, dan Pasal 22 UU Nomor 39 Tahun 2008 tentang Kementerian Negara

${ }^{45}$ Original intent perubahan Pasal 17 UUD 1945 juga tidak menyebutkan sama sekali adanya usulan atau wacana kewenangan presiden mengangkat Wamen. Lihat lebih lanjut dalam Tim Penyusunan Naskah Komprehensif proses dan Hasil Perubahan UUD 1945, Naskah Komprehensif Perubahan UUD NRI 1945 Tabun 1945 buku IV tentang Kekuasaan Pemerintahan Negara Jilid 2, Sekretariat Jenderal dan Kepaniteraan MK, Jakarta, 2010. 
tangan presiden dan belum mencerminkan adanya semangat pembatasan kekuasaan presiden. Argumen ini terlihat dari luasnya parameter bagi presiden untuk mengangkat Wamen dengan hanya mendasarkan adanya beban kerja yang membutuhkan penanganan khusus sebagai landasan hukum bagi presiden dalam mengangkat Wamen.

Tidak terdapat parameter yang jelas mengenai apa yang dimaksud sebagai beban kerja yang membutuhkan penanganan khusus dalam mengangkat Wamen tersebut sehingga memberikan ruang lebar kepada presiden untuk menentukan besaran jumlah Wamen yang akan ia angkat. Terdapat beragam besaran jumah Wamen yang diangkat dalam praktik pengangkatan Wamen di beberapa rezim presiden. Rezim Presiden SBY mengangkat 19 orang Wamen ${ }^{46}$ dan Rezim Presiden Jokowi mengangkat 12 orang Wamen, bahkan dalam kementerian BUMN diangkat 2 orang Wamen. ${ }^{47}$ Besarnya jumlah Wamen ini menambah gemuk susunan kabinet yang maksimal sudah berisi 34 kementerian ${ }^{48}$ sehingga tidak sejalan dengan semangat pembentukan UU Kementerian Negara yang menginginkan adanya efektifitas dan efisiensi dalam membentuk kementerian negara. 49

Terdapat pula pergeseran pengaturan status Wamen menjadi jabatan politik pasca dikeluarkannya Putusan MK No.79/PUU-IX/2011. Berubahnya status Wamen menjadi jabatan politik ini memberikan ruang lebih lebar bagi presiden untuk mengangkat Wamen baik berasal dari pegawai negeri ataupun non-pegawai negeri (kalangan profesional maupun politik). Sebelumnya, Penjelasan Pasal 10 UU Kementerian Negara tegas mengatur status Wamen sebagai jabatan karir dan bukan anggota kabinet sehingga pengisiannya harus berasal dari pegawai negeri yang memiliki kompetensi dan memenuhi karir birokrasi tertentu.

Praktik pengangkatan Wamen dari kalangan non birokrasi ini terlihat dalam beberapa rezim presiden. Tercatat, rezim Presiden SBY mengangkat 19 orang Wamen yang berasal dari 7 orang birokrat dan 12 orang berasal dari non

\footnotetext{
46 "SBY Kini Punya 19 Wakil Menteri”, Loc. Cit

47 "Komposisi Wakil Menteri Jokowi 5 dari Parpol, 5 dari Professional serta Timses", Loc. Cit

48 Pasal 15 UU Nomor 39 Tahun 2008 tentang Kementerian Negara

49 Lihat Pendapat Mahkamah dalam Putusan MK Nomor 79/PUU-IX/2011, hlm. 78
} 
birokrat/profesional..$^{50}$ Sementara, pada rezim Presiden Jokowi jilid kedua, sama sekali tidak mengangkat Wamen dari kalangan birokrat. Presiden Jokowi mengangkat 12 Wamen yang terdiri dari 5 orang berlatar belakang profesional serta 7 orang dari basis pendukung jokowi, baik berasal dari Parpol atau berasal dari sukarelawan serta tim pemenangan jokowi-ma'aruf. ${ }^{51}$

Terlihat pengangkatan Wamen dalam perjalanannya mengindikasikan adanya kecenderungan bagi presiden dalam mengangkat Wamen dari kalangan non birokrasi. Bahkan, pada rezim presiden Jokowi lebih dari 50\% pos Wamen diisi dari basis pendukung Jokowi, baik yang berasal dari Parpol maupun sukarelawan. ${ }^{52}$ Praktik ini menunjukan adanya kecenderungan dominasi kepentingan politik presiden dalam pengangkatan Wamen, bukan dilandasi atas keahlian tertentu guna mengatasi adanya beban kerja khusus yang menjadi dasar pengangkatan Wamen.

Ketiadaan ketentuan syarat-syarat menjadi Wamen juga memberikan peluang kepada presiden untuk mengangkat Wamen yang dimungkinkan tidak setia kepada Pancasila, UUD 1945, dan cita-cita proklamasi, tidak memiliki integritas dan kepribadian yang baik;dan mantan narapidana yang diancam dengan pidana penjara 5 (lima) tahun atau lebih. Adanya ruang pengaturan lewat peraturan presiden (Perpres) juga bukan menjadi solusi. ${ }^{53}$ Hal ini karena pembentukan Perpres yang merupakan kewenangan tunggal presiden dan disertai dengan ketiadaan ketentuan pembatasan dalam UU akan memberikan ruang penafsiran yang lebar kepada presiden sesuai kehendak politiknya. ${ }^{54}$

50 Pengangkatan 19 orang Wamen ini sebelumnya dipicu oleh dikeluarkannya Perpres No. 76 Tahun 2011 yang menghapuskan ketentuan Wamen harus berasal dari pegawai negeri yang telah menduduki jabatan eselon I.a. Namun UU Kementerian Negara masih menempatkan syarat Wamen sebagai jabatan karir. Fajrul Falaakh mengistilahkan kondisi ini dengan istilah politisasi jabatan karir. Lebih lanjut lihat pendapat Fajrul Falaakh dalam, Mohammad Saihu, dkk, Mohammad Fajrul Falaakh ..., Loc. Cit

51 "Komposisi Wakil Menteri Jokowi 5 dari Parpol, 5 dari Professional serta Timses", Loc. Cit

52 Jokowi mengangkat 7 Wamen dari unsur politik dan sukarelawan pemenangan Jokowi-Ma'aruf dari 12 Wamen yang diangkat, lihat "Komposisi Wakil Menteri Jokowi 5 dari Parpol, 5 dari Professional serta Timses", Loc. Cit

53 Minimnya pengaturan terkait Wamen dalam UU Kementerian Negara kemudian memicu adanya praktik pengaturan lebih lanjut lewat Perpres. Tercatat ketentuan lebih lanjut mengenai Wamen hadir dalam Perpres No. 47 Tahun 2009 tentang pembentukan dan organisasi kementerian negara beserta perubahannya serta hadir lewat Perpres No. 60 Tahun 2012 tentang Wakil Menteri.

${ }^{54}$ Praktik ini terjadi dengan dikeluarkannya Perpres No. 76 Tahun 2011 yang menghapuskan ketentuan wamen harus berasal dari pegawai negeri yang telah menduduki jabatan eselon I.a. Namun, UU Kementerian Negara masih menempatkan syarat Wamen sebagai jabatan karir. Fajrul Falaakh mengistilahkan kondisi ini dengan istilah politisasi jabatan karir. Lebih lanjut lihat pendapat Fajrul Falaakh dalam Mohammad Saihu, dkk, Mohammad Fajrul Falaakh ..., Loc. Cit. 
Ketentuan terkait pengangkatan Wamen ini jauh berbeda dengan ketentuan terkait pembentukan, perubahan, dan penggabungan kementerian yang melibatkan DPR sebagai kekuatan penyeimbang bagi presiden. Selain itu, UU Kementerian Negara juga memberikan parameter bagi presiden dalam membentuk kementerian ${ }^{55}$ serta mengatur adanya syarat-syarat yang harus dimiliki seseorang untuk diangkat menjadi menteri. 56

MK di sisi lain menyatakan bahwa penilaian atas frasa beban kerja yang membutuhkan penanganan khusus menjadi wewenang presiden untuk menentukannya sebelum mengangkat Wamen tetapi MK juga menyatakan bahwa kewenangan presiden mengangkat Wamen dalam rangka menangani beban kerja yang semakin berat tidak bertentangan dengan konstitusi jika dipandang dari sudut pengutamaan tujuan yang hendak dicapai (doelmatigheid) atau nilai kemanfaatan dalam rangka memenuhi harapan dan kebutuhan masyarakat yang terus meningkat. ${ }^{57}$ Artinya, pembentukan dan pengangkatan seseorang menjadi Wamen tidaklah tanpa batas namun harus didasarkan untuk memenuhi harapan dan kebutuhan masyarakat yang terus meningkat.

Adanya parameter yang diberikan MK ini justru masih memberikan celah yang begitu lebar bagi presiden dalam mengangkat Wamen. Padahal, bukan berarti apa yang menjadi kekuasaan presiden itu tidaklah memiliki batasan. Secara teoritik, sistem pemerintahan presidensial memang menempatkan kekuasaan yang kuat kepada presiden karena menempatkan kedudukan presiden secara independen dan terpisah dari badan lain. ${ }^{58}$ Oleh karenanya, dalam sistem presidensial ini dikenal pula adanya hak prerogatif presiden. Mahfud MD memaknai hak prerogatif presiden sebagai hak istimewa yang dimiliki oleh presiden untuk melakukan sesuatu tanpa meminta persetujuan lembaga lain.59

Sedikit berbeda dengan pendapat Mahfud MD di atas, Bagir Manan berpandangan bahwa, hak prerogatif justru memperlihatkan sifat undemocratic and potentially dangerous. Selain itu, pemaknaan hak prerogatif yang

\footnotetext{
55 Pasal 13 UU Nomor 39 Tahun 2008 tentang Kementerian Negara

${ }_{56}$ Pasal 22 UU Nomor 39 Tahun 2008 tentang Kementerian Negara

${ }^{57}$ Lihat Putusan MK No. 79/PUU-IX/2011 mengenai pengujian UU No. 39 Tahun 2008 tentang Kementerian Negara, hlm.77.

58 Saldi Isra, Pergeseran Fungsi Legislatif..., Op. Cit., hlm. 40.

${ }^{59}$ Moh. Mahfud, Hukum dan Pilar-Pilar Demokrasi, Gama Media, Yogyakarta, 1999, hlm. 258.
} 
menempatkan besarnya kekuasaan di tangan presiden tidaklah cocok ditempatkan di negara democratische reechstaat yang menghendaki adanya pembatasan kekuasaan dalam pemerintahan.60 Oleh karenanya, untuk mengurangi sifat tidak demokratik dan bahaya-bahaya tersebut, maka penggunaan kekuasaan prerogatif dibatasi dan dialihkan ke dalam undangundang serta kemungkinan untuk diuji melalui peradilan (judicial revieww). ${ }^{61}$

Bagir Manan juga mengatakan bahwa suatu kekuasaan prerogatif yang sudah diatur dalam undang-undang tidak disebut sebagai hak prerogatif lagi, melainkan sebagai hak yang berdasarkan undang-undang. Terdapat 5 karakter kekuasaan prerogatif, yakni:62

1. Sebagai residual power;

2. merupakan kekuasaan diskresi (freis ermessen);

3. tidak ada dalam hukum tertulis;

4. penggunaan dibatasi;dan

5. akan hilang apabila telah diatur dalam undang-undang, atau UUD.

Oleh karenanya, dapat dikatakan bahwa kekuasaan presiden yang telah diletakkan dalam UUD maupun UU, termasuk kewenangan mengangkat Wamen tidak bisa dikatakan sebagai hak prerogatif presiden sehingga melekat dengan adanya semangat pembatasan kekuasaan terhadap presiden.

Berdasarkan uraian tersebut, terlihat bahwa pengaturan kewenangan presiden mengangkat Wamen dalam UU Kementerian Negara belum mencerminkan semangat pembatasan kekuasaan terhadap presiden. Oleh karenanya, sebagai bagian dari kekuasaan presiden, terdapat urgensi pembatasan kekuasaan terhadap presiden dalam mengangkat Wamen.

Bentuk pembatasan ini bisa diwujudkan dengan memberikan ketentuan syarat-syarat khusus bagi seseorang untuk diangkat menjadi Wamen seperti syarat yang diberikan kepada menteri.63 Perlu ditambahkan pula syarat memiliki keahlian tertentu guna menangani adanya beban kerja yang membutuhkan

60 Ni'matul Huda, Presiden dan Pembantu Presiden..., Op. Cit., hlm. 212-213.

${ }^{61}$ Ibid

${ }^{62}$ Ibid

${ }^{63}$ Syarat ini seperti, (1) warga negara Indonesia, bertakwa kepada Tuhan Yang Maha Esa, setia kepada Pancasila, UUD NRI 1945, dan cita-cita proklamasi kemerdekaan, sehat jasmani dan rohani; memiliki integritas dan kepribadian yang baik;dan tidak pernah dipidana penjara berdasarkan putusan pengadilan yang inkrach karena melakukan tindak pidana yang diancam dengan pidana penjara 5 tahun atau lebih. Lihat Pasal 22 ayat (2) UU Nomor 39 Tahun 2008 tentang Kementerian Negara 
penanganan khusus sebagai alasan diangkatnya Wamen. Selain itu, perlu adanya indikator tambahan bagi presiden dalam membentuk Wamen, seperti indikator bagi presiden dalam membentuk kementerian. ${ }^{64}$ Pilihan pembatasan lewat diberikannya syarat dan indikator tertentu dalam undang-undang ini sejalan dengan konsep pembatasan kekuasaan pemerintah lewat undang-undang (government limited by law). 65

Pembatasan kekuasaan bisa juga diberikan dengan cara melibatkan DPR sebagai kekuatan penyeimbang (check and balances) bagi presiden dalam pembentukan Wamen. ${ }^{66}$ Agar tidak terlalu mengekang presiden, pelibatan DPR ini diwujudkan dalam bentuk pemberian pertimbangan kepada presiden sebelum membentuk Wamen, bukan dalam mengangkat seseorang menjadi Wamen. Forum pertimbangan ini harus dilakukan secara transparan dan terbuka sebagai ruang uji publik presiden kepada rakyat yang diwakili oleh DPR.

\section{Penutup}

Berdasarkan pembahasan di atas, maka dapat diambil dua kesimpulan, pertama, terdapat dinamika pengaturan pengangkatan Wamen oleh presiden pasca reformasi. UU Kementerian Negara menempatkan Wamen sebagai jabatan karir sehingga presiden hanya dapat menunjuk Wamen dari kalangan Pegawai Negeri Sipil atau pejabat karir dengan keahlian tertentu. Ketentuan ini diubah lewat Putusan MK No. 79/PUU-IX/2011 yang mengakibatkan bergesernya kedudukan Wamen sebagai jabatan politik sehingga memperluas kewenangan presiden untuk mengangkat Wamen dari kalangan manapun.

Kedua, UU Kementerian Negara belum mencerminkan adanya pembatasan kekuasaan terhadap presiden dalam mengangkat Wamen. UU Kementerian Negara hanya mencantumkan syarat adanya "beban kerja yang membutuhkan penanganan khusus" dalam membentuk Wamen dan tanpa mengatur adanya syarat-syarat bagi seseorang untuk dapat diangkat sebagai Wamen. Adanya celah

${ }^{64}$ Indikator ini seperti, (1) efisiensi dan efektivitas; (2) cakupan tugas dan proporsionalitas beban tugas; (3) kesinambungan, keserasian, dan keterpaduan pelaksanaan tugas; dan/atau perkembangan lingkungan global. Lihat ketentuan Pasal 13 ayat (2) UU Nomor 39 Tahun 2008

${ }^{65}$ Govenrment limited by law merupakan salah satu unsur pokok dari negara hukum (rule of law). Lihat Brian Z. Tamanaha, "The History and Elements ..., Loc. Cit

${ }^{66}$ Pelibatan DPR ini menjadi salah satu cara pembatasan kekuasaan dengan prinsip check and balance, lihat Munir Fuadi, Teori Negara Hukum Modern ..., Loc. Cit 
ini dalam praktiknya memperlihatkan kecenderungan dominasi kepentingan politik presiden dalam membentuk dan mengangkat Wamen sehingga tidak sejalan dengan semangat efektivitas dan efisiensi dalam membentuk kementerian negara. Padahal, kewenangan mengangkat Wamen, tidak dapat dikatakan sebagai hak prerogatif presiden, sehingga seharusnya melekat pula dengan semangat pembatasan kekuasaan terhadap presiden sebagai salah satu asas dalam agenda amendemen UUD 1945.

Berdasarkan kesimpulan tersebut, penulis memberikan saran kepada pembentuk UU untuk melakukan perbaikan terhadap UU Kementerian Negara dengan memberikan pembatasan kekuasaan terhadap presiden dalam mengangkat Wamen lewat diaturnya syarat-syarat tertentu bagi seseorang untuk diangkat menjadi Wamen, diberikannya indikator-indikator yang lebih terukur bagi presiden dalam membentuk Wamen, dan dilibatkannya DPR untuk memberikan pertimbangan kepada presiden sebelum membentuk Wamen.

\section{Daftar Pustaka}

\section{Buku}

Asshiddiqie, Jimly, Format Kelembagaan Negara dan Pergeseran Kekuasaan dalam UUD 1945, FH UII Press, Yogyakarta, 2004.

Budiarjo, Miriam, Dasar-Dasar Ilmu Politik, edisi revisi, Gramedia, Jakarta, 2008.

Fuadi, Munir, Teori Negara Hukum Modern (rechtstaat), PT. Refika Aditama, Bandung, 2009.

Huda, Ni'matul, Hukum Tata Negara Indonesia, ctk. kesembilan, Rajawali Press, Yogyakarta, 2014.

Presiden dan Pembantu Presiden dalam Sistem Ketatanegaraan Indonesia, ctk. pertama, FH UII Press, Yogyakarta, 2019.

Kamis, Margarito, Kekuasaan Presiden Indonesia: Sejarah Kekuasaan Presiden Sejak Merdeka Hingga Reformasi Politik, ctk. Pertama, Setara Press, Malang, 2014.

_. Pembatasan Kekuasaan Presiden: Pergeseran Kekuasaan Presiden Pasca Amendemen UUD 1945, Ctk.Pertama, Setara Press, Malang, 2014.

Mahfud, Moh, Hukum dan Pilar-Pilar Demokrasi, Gama Media, Yogyakarta, 1999.

Saihu, Mohammad, dkk, Mohammad Fajrul Falaakh Konsisten Mengawal Konstitusi, Ctk. Pertama, Perpustakaan Nasional RI, Jakarta, 2014.

Yuda, Hanta, Presidensialisme Setengah Hati, ctk. Pertama, Gramedia Pustaka Utama, Jakarta, 2010. 
Jurnal

Aidin, "Kedudukan Wakil Menteri Dalam Sistem Ketatanegaraan Republik Indonesia", Jurnal IUS Kajian Hukum dan Keadilan, Vol. II, No. 5, Agustus, 2014.

Muntoha, “Demokrasi dan Negara Hukum”, Jurnal Hukum, Vol. 16, No. 3, Juli, 2009.

M. Yasin al-Arif, "Anomali Sistem Pemerintahan Presidensial Pasca Amendemen UUD 1945”, Jurnal Hukum Ius Quia Iustum, Vol. 22, No. 2, April, 2015.

M. Termosjuizent, "The Concept Rule Of Law", Jentera, Edisi 3, Tahun II, November, 2004.

Brian Z. Tamanaha, "The History and Elements of The Rule Of Law", Singapore Journal of Legal Studies, 2012.

\section{Website}

“SBY Kini Punya 19 Wakil Menteri”, https:/ / nasional.tempo.co/read/ 361705/sbykini-punya-19-wakil-menteri, diakses pada tangal 5 April 2020.

"Komposisi Wakil Menteri Jokowi 5 dari Parpol, 5 dari Professional serta Timses", https: / /nasional.kompas.com/read/2019/10/25/16234391/komposisiwakil-menteri-jokowi-5-dari-parpol-5-profesional-serta-timsesdan?page=all, diakses pada tanggal 29 September 2020 .

"Wakil Menteri Kabinet Jokowi; Antara Kompromi Politik dan Pemborosan Anggaran", $\quad$ https://www.bbc.com/indonesia/indonesia-50179625, diakses pada tangal 5 April 2020.

\section{Peraturan Perundang-Undangan dan Risalah Sidang}

Undang-Undang Dasar Negara Republik Indonesia Tahun 1945 sebelum amandemen dan setelah amandemen.

Undang-Undang Nomor 39 Tahun 2008 tentang Kementerian Negara (Lembaran Negara RI Tahun 2008 Nomor 166, Tambahan Lembaran Negara RI Nomor 4916).

Peraturan Presiden Nomor 47 Tahun 2009 jo Peraturan Presiden Nomor 76 Tahun 2011 tentang Pembentukan dan Organisasi Kementerian Negara.

Peraturan Presiden Nomor 60 Tahun 2012 tentang Wakil Menteri

DPR RI, Risalah Rapat Kerja Panitia Khusus RUU Tentang Kementerian Negara, Kamis 16 Oktober 2008.

Tim Penyusunan Naskah Komprehensif Proses dan Hasil Perubahan UUD 1945, Naskah Komprehensif Perubahan UUD NRI 1945 Tahun 1945 buku IV: tentang Kekuasaan Pemerintahan Negara Jilid 2, Sekretariat Jenderal dan Kepaniteraan MK, Jakarta, 2010. 


\section{Putusan MK}

Putusan MK Nomor 79/PUU-IX/2011 tentang pengujian atas Undang-Undang Nomor 38 Tahun 2008 tentang Kementerian Negara. 